VELÁZQUEZ SEIFERHELD David; D'ALESSANDRO, Sandra. Relaciones entre autoritarismo y educación en el Paraguay (1869-2012). Un análisis histórico (Vol. III: 19541989). Assunção: SERPAJ-PY, 2018, 147p.

\title{
FACES DO AUTORITARISMO NO PARAGUAI: A EDUCAÇ̃̃O COMO FERRAMENTA DE LEGITIMAÇÃO, CONSTRUÇÃO DE CONSENSO E REPRODUÇÃO DO STRONISMO
}

Marcela Cristina Quinteros*

Em 2014, a equipe de Educação em Direitos Humanos e Cultura da Paz, do Serviço Paz e Justiça do Paraguai (SERPAJ-PY), dava a conhecer o primeiro de quatro volumes de uma coleção que busca estabelecer as Relações entre autoritarismo e educação no Paraguai (18692012). Cada tomo é dedicado a um período da história paraguaia, sendo que o primeiro compreende de 1869 a 1930 (publicado em 2014), o segundo, de 1931 a 1954 (2016), e o terceiro, de 1954 a 1989 (2018), que coincide com o stronismo. Faltando ainda o último volume, a coleção conta com uma equipe de pesquisa integrada por Ana Barreto, David Velázquez Seiferheld e Sandra D’Alessandro, coordenada por Ignacio Telesca. A autoria do terceiro volume, apresentado aqui, corresponde a Velázquez Seiferheld e a D’Alessandro.

Ao apresentarem um balanço sobre os nexos entre autoritarismo e educação durante o stronismo, os autores se depararam com a necessidade de expor as principais interpretações que tentam explicar as causas da longevidade da ditadura de Alfredo Stroessner (1954-1989), para assim poder apresentar as fases e os principais elementos do desenvolvimento do ensino durante esse período no Paraguai. A tarefa, a princípio, hercúlea, é narrada a partir de uma linguagem que, sem abandonar o rigor científico, é acessível ao público em geral. O objetivo dos autores é mostrar à população paraguaia alguns dos mecanismos utilizados pelo stronismo para garantir sua sobrevivência ao longo de 35 anos, sendo a educação um fator chave para entender a permanência de um modelo autoritário bem-sucedido.

\footnotetext{
* Licenciada e Bacharel em História pela Universidade Nacional de Córdoba (Argentina), Mestre e Doutora em História Social pela USP, Pós Doutora en História pela PUC-SP e Pós Doutoranda pela UFGD. Autora e organizadora de livros como "Os olhos da Nação" e "As Revoluções na América Latina", além de artigos sobre a história latino-americana em geral e sobre a história paraguaia em particular. Membro fundadora da Rede de Pesquisadoras e Pesquisadores de História do Paraguai Nande.
} 
O texto começa com uma introdução em que expõe diversas práticas autoritárias adotadas pelo stronismo, preexistentes ao regime e que ainda o sobreviveram após a queda de Alfredo Stroessner, em 1989. A novidade - e o sucesso - do regime foi a sua sistematização, a sua renovação e o seu aperfeiçoamento, de modo tal que se mostrou "inesperadamente eficiente", nas palavras dos autores. Ao contrário das análises feitas em boa parte dos estudos sobre o stronismo, que salientam sua faceta repressiva e a violação aos direitos humanos, a contribuição deste livro é indagar, basicamente, sobre como o ensino formal contribuiu para a reprodução e a duração do regime.

Os autores - assim como a equipe de pesquisadores - pertencem a uma geração de jovens historiadores paraguaios que tiveram a oportunidade de fazer a graduação e a pósgraduação no Paraguai, em uma fase da história nacional em que lutava-se por deixar para atrás décadas de autoritarismo e dava-se a renovação dos cursos de História e Ciências Sociais, ao mesmo tempo em que começavam os cursos de pós-graduação. A reabertura democrática favoreceu o retorno de intelectuais exilados e o intercâmbio com historiadores rio-platenses, renovando a pesquisa e reabilitando um diálogo necessário para a reconstrução histórica não apenas do Paraguai como de toda a região.

Partindo de algumas poucas publicações existentes sobre a história da educação no Paraguai, mas principalmente das próprias pesquisas, os autores analisam diferentes aspectos a partir de distintos tipos de fontes e abordagens que permitem refletir sobre temas ainda pouco explorados, como as estratégias para a construção de consenso e legitimação do regime. Assim, são analisados livros didáticos, documentos do Ministério de Educação, projetos de reforma e planos educativos implementados, documentos tanto dos centros acadêmicos como das agremiações docentes, entrevistas orais, jornais e revistas, além de materiais novos surgidos após a descoberta e/ou reorganização de arquivos (tais como o Arquivo do Terror, onde foram encontrados livros didáticos utilizados nas escolinhas das Ligas Agrárias Camponesas), entre outros documentos.

O livro, organizado em seis capítulos, começa enumerando as características do regime, tais como o exercício discricional do poder; a repressão; a "lealdade" imposta pelo Partido de Stroessner, o Colorado; a propaganda governamental; o militarismo; o nacionalismo; o culto à personalidade; a economia controlada pelo Estado; a cooperação econômica com os EUA; a permanente oposição entre os governos anteriores - caracterizados como instáveis - e o de Stroessner - apresentado como pacificador e artífice do progresso do país. Por último, os 
autores se referem à concentração do poder por parte de Stroessner, que controlava o governo, o partido e as Forças Armadas, reforçando o argumento clássico de que esta seria uma das principais causas da longevidade do regime, embora tenha sido o resultado de um longo processo.

No segundo capítulo, é apresentado um panorama das políticas educativas entre 1954 e 1989. Em primeiro lugar, se salienta o crescimento demográfico, a incipiente urbanização e uma lenta e parcial modernização da economia que favoreceram o crescimento da matrícula nos níveis fundamental e médio. Percebe-se que a educação deixava de ser privilégio das elites e convertia-se em fator de mobilidade social. Em segundo lugar, são examinadas as duas reformas educativas do período: a de 1957 e a de 1973. Enquanto a primeira buscou universalizar o ensino médio, na tentativa de que deixasse de ser uma etapa preparatória para a universidade e oferecesse uma formação integral do indivíduo, a segunda se orientava à capacitação do aluno para o mercado de trabalho, sendo significativa a diminuição das horas de Ciências Sociais.

No terceiro capítulo, é destacada a importância que o próprio Stroessner deu à educação em seus discursos e através de sua participação pessoal em inaugurações, entrega de materiais e atos escolares. Com o stronismo, foi consolidada uma disciplina militar nas escolas (desfiles, músicas, etc.) como o controle ideológico através do prisma do nacionalismo paraguaio, que legitimava intervenções, perseguições, suspensões e repressão de movimentos estudantil e docente.

No quarto capítulo, são analisados os instrumentos da educação, como os programas de estudo, o uso do espanhol como única língua de ensino e os livros didáticos. O exame dos programas reflete o progressivo abandono das Ciências Sociais e a preeminência da matemática e da língua espanhola. As disciplinas História, Geografia e Educação Cívica, agrupadas na área das Ciências Sociais a partir de 1973, serviram como marco para a divulgação do nacionalismo e de uma história centrada nos grandes homens. Os autores dão atenção especial aos livros didáticos, demostrando que alguns historiadores, editoras e versões da história eram hegemônicos. Luis Benítez se destaca entre as vozes autorizadas pelo regime à escrita dos livros de história para todos os níveis (fundamental, médio, superior). Além de oferecer uma história segundo o revisionismo paraguaio, é o único autor que inclui o período stronista e o faz de um modo laudatório. A preeminência de Benítez na formação tanto de crianças e adolescentes como de docentes indica o papel homogeneizador da escola, com um discurso que nega os conflitos 
na história e tende a formar os estudantes na ideia de harmonia como estratégia para prever futuros conflitos.

No quinto capítulo, são analisadas as representações presentes nos recursos educativos (livros, programas, etc.), a partir da análise do discurso. Uma dessas representações corresponde a questões de gênero, principalmente nos textos da educação infantil, nos quais aparecem bem delimitados os papéis masculino e feminino segundo um modelo patriarcal conservador. Outra representação que se impõe nos textos é o papel dos grandes homens, principalmente o de Stroessner, identificado como o "reconstrutor" e o "pacificador" do Paraguai.

Por último, no sexto capítulo, os autores mergulham em alguns conflitos marcantes, como as greves estudantis, as escolas das Ligas Agrárias Camponesas e as intervenções em colégios particulares. Especificamente, é relatado como se organizou a primeira grande greve estudantil nos primeiros anos do stronismo, em 1959, em protesto contra o aumento do preço da passagem do transporte e que terminou em uma brutal repressão e no exílio interno das principais lideranças. A intervenção do Colégio Cristo Rei de Assunção serve como exemplo da aplicação dos mecanismos de controle ideológico e perseguição do regime que determinou a expulsão maciça de seu corpo docente, além da tortura e do assassinato de um de seus professores. Por fim, a organização das Ligas Agrárias Camponesas, com o apoio de sacerdotes da Teologia da Libertação, demandou a criação de suas próprias escolas, porque as oficiais não contemplavam a idiossincrasia dos camponeses, muitos deles, indígenas. A experiência, relatada a partir da história oral, não teve vida longa, dado os diversos mecanismos de censura, perseguição, repressão e expulsão das lideranças.

O livro representa um grande aporte para o estudo do stronismo, ao trazer uma reflexão sobre a importância de estudar aspectos que contribuem para sustentar o regime através do consenso e da identificação ideológica. O estudo feito por Velázquez Seiferheld e D’Alessandro oferece tanto um balanço da história da educação no Paraguai quanto questões que podem orientar pesquisas futuras. De fato, algumas pesquisas estão em curso, havendo um interesse especial na análise dos textos didáticos. Mas, ainda há um campo significativamente amplo por explorar, para responder melhor à pergunta de por que, no Paraguai, o stronismo se manteve no poder durante 35 anos. 